\title{
Ocean warming is the key filter for successful colonization of the migrant octocoral Melithaea erythraea Ehrenberg, 1834 in the Eastern Mediterranean Sea
}

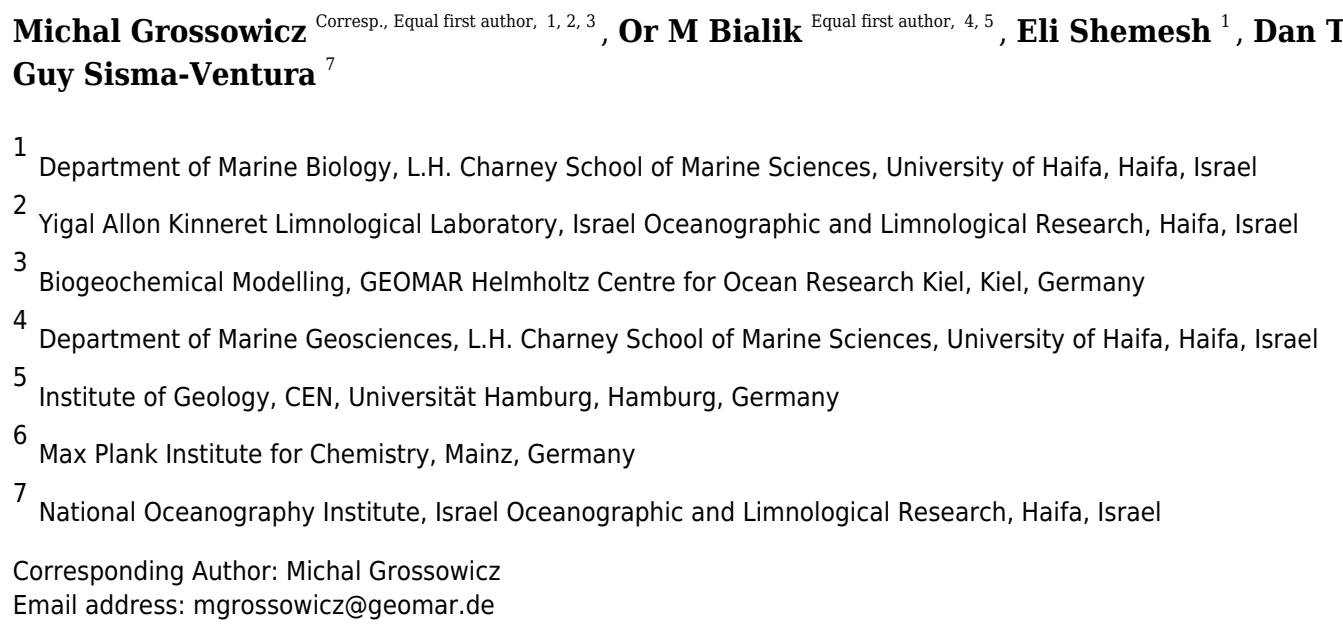

Climate, which sets broad limits for migrating species, is considered a key filter to species migration between contrasting marine environments. The Southeast Mediterranean Sea (SEMS) is one of the regions where ocean temperatures are rising the fastest under recent climate change. Also, it is the most vulnerable marine region to species introductions. Here, we explore the factors which enabled the colonization of the endemic Red Sea octocoral Melithaea erythraea Ehrenberg, 1834 along the SEMS coast, using sclerite oxygen and carbon stable isotope composition $\left(\delta^{18} \mathrm{O}_{\mathrm{SC}}\right.$ and $\left.\delta^{13} \mathrm{C}_{\mathrm{SC}}\right)$, morphology, and crystallography. The unique conditions presented by the SEMS include a greater temperature range $\left(\sim 15^{\circ} \mathrm{C}\right)$ and ultra-oligotrophy, and these are reflected by the lower $\delta^{13} \mathrm{C}_{\mathrm{sc}}$ values. This is indicative of a larger metabolic carbon intake during calcification, as well as an increase in crystal size, a decrease of octocoral wart density and thickness of the migrating octocoral sclerites compared to the Red Sea samples. This suggests increased stress conditions, affecting sclerite deposition of the SEMS migrating octocoral.

The $\delta^{18}$ Osc range of the migrating $M$. erythraea indicates a preference for warm water sclerite deposition, similar to the native depositional temperature range of $21-28{ }^{\circ} \mathrm{C}$. These findings are associated with the observed increase of minimum temperatures in winter for this region, at a rate of $0.35 \pm 0.27^{\circ} \mathrm{C}$ decade ${ }^{-1}$ over the last 30 years, and thus the region is becoming more hospitable to the Indo-Pacific M. erythraea. This study shows a clear case study of "tronicalization" of the Mediterranean Sea due to recent warming.
Peer) reviewing PDF ( $2020: 02: 45922: 1: 1:$ NEW 15 May 2020) 


\section{Ocean warming is the key filter for successful colonization of the migrant}

2 octocoral Melithaea erythraea Ehrenberg, 1834 in the Eastern Mediterranean

\section{Sea}

5 Warming enables migration of Melithaea

6

7 Michal Grossowicz ${ }^{1,2,3 *}$, Or M. Bialik ${ }^{4,5}$, Eli Shemesh ${ }^{1}$, Dan Tchernov ${ }^{1}$, Hubert B. Vonhof ${ }^{6}$, 8 Guy Sisma-Ventura ${ }^{7}$

9

10

MG and OMB are equal first authors

${ }^{1}$ Department of Marine Biology, L.H. Charney School of Marine Sciences, University of Haifa, Haifa, Israel.

${ }^{2}$ Yigal allon Kinneret Limnological Laboratory, Israel Oceanographic and Limnological Research, Haifa, Israel.

${ }^{3}$ Biogeochemical modelling, GEOMAR Helmholtz Centre for Ocean Research, Kiel, Germany.

${ }^{4}$ Department of Marine Geosciences, L.H. Charney School of Marine Sciences, University of Haifa, Haifa, Israel.

${ }^{5}$ Institute of Geology, CEN, University of Hamburg, Hamburg, Germany.

${ }^{6}$ Max Planck Institute for Chemistry, Mainz, Germany

${ }^{7}$ National Oceanography Institute, Israel Oceanographic and Limnological Research, Haifa, Israel.

*Corresponding author: MG (mgrossowicz@geomar.de) 


\section{Abstract}

33 Climate, which sets broad limits for migrating species, is considered a key filter to species 34 migration between contrasting marine environments. The Southeast Mediterranean Sea (SEMS) is 35 one of the regions where ocean temperatures are rising the fastest under recent climate change. 36 Also, it is the most vulnerable marine region to species introductions. Here, we explore the factors 37 which enabled the colonization of the endemic Red Sea octocoral Melithaea erythraea Ehrenberg, 381834 along the SEMS coast, using sclerite oxygen and carbon stable isotope composition $\left(\delta^{18} \mathrm{O}_{\mathrm{SC}}\right.$ 39 and $\delta^{13} \mathrm{C}_{\mathrm{SC}}$ ), morphology, and crystallography. The unique conditions presented by the SEMS

40 include a greater temperature range $\left(\sim 15^{\circ} \mathrm{C}\right)$ and ultra-oligotrophy, and these are reflected by the 41 lower $\delta^{13} \mathrm{C}_{\mathrm{SC}}$ values. This is indicative of a larger metabolic carbon intake during calcification, as 42 well as an increase in crystal size, a decrease of octocoral wart density and thickness of the 43 migrating octocoral sclerites compared to the Red Sea samples. This suggests increased stress 44 conditions, affecting sclerite deposition of the SEMS migrating octocoral. The $\delta^{18}$ Osc range of the migrating $M$. erythraea indicates a preference for warm water sclerite deposition, similar to the native depositional temperature range of $21-28^{\circ} \mathrm{C}$. These findings are associated with the observed increase of minimum temperatures in winter for this region, at a rate of $0.35 \pm 0.27{ }^{\circ} \mathrm{C}$ decade $^{-1}$ over the last 30 years, and thus the region is becoming more hospitable to the Indo-Pacific M. erythraea.

49 This study shows a clear case study of "tropicalization" of the Mediterranean Sea due to recent warming.

\section{Key-words}

52 Sea-surface warming; Tropicalization; Lessepsian migration; Octocoral sclerites; Stable isotopes;

53 Crystallography 


\section{Introduction}

56 Increasing global temperatures caused by recent climate change may impose a dramatic effect on

57 the structure and function of ecosystems worldwide (Lejeusne et al., 2009; Burrows et al., 2011).

58 Long-term records suggest that the greatest impact of climate change on biotic communities might

59 be due to shifts in the maximum and minimum temperatures as well as short-term climatic events,

60 rather than changes in mean annual temperatures (Stachowicz et al., 2002). Temperature, as a

61 function of climate, is considered a key filter that could determine the success of introduced marine

62 species (Theoharides and Dukes, 2007). Introduced species are defined as living outside their

63 native distributional range through deliberate or accidental human activity. The thermal regime

64 sets broad limits on the distribution of the introduced species that may cause such taxa to fail at

65 the early stages of settlement (Hewitt and Hayes, 2002; Mack et al., 2000). Under the right

66 environmental conditions and ecosystem fragility, an introduced species may become invasive,

67 i.e., a pest in its new location, which spreads by natural means (Ehrenfeld, 2010). Understanding

68 how these long-term fluctuations in environmental conditions facilitate the introduction and

69 successful colonization is of prime importance for developing better predictions regarding the

70 ecological effects of future climate change.

The southeastern Mediterranean Sea (SEMS), which is one of the most rapidly warming

72 regions under recent climate change (Sisma-Ventura, Yam and Shemesh, 2014; Ozer et al., 2016),

73 offers a natural laboratory to study the process of species introduction in the context of global

74 warming (Béthoux et al., 1999). Recent field studies have shown that increased maximum

75 temperatures in the Mediterranean have led, inter alia, to multi-species collapse (Rilov, 2016),

76 increased seagrass mortality (Jordà, Marbà and Duarte, 2012), and a general shift to 'warm-water'

77 species (Chevaldonné and Lejeusne, 2003; Lejeusne et al., 2009; Raitsos et al., 2010; Rilov and 
78 Galil, 2009). This process was previously defined as "tropicalization" of the Mediterranean fauna 79 (Bianchi and Morri, 2003).

80 Increased stratification, due to the recent warming of the eastern Mediterranean surface layer

81 (Ozer et al., 2016; Sisma-Ventura et al., 2017), as well as damming of its main freshwater sources

82 (Ludwig et al., 2009; Bialik and Sisma-Ventura, 2016), resulted in a severe nutrient deficiency

83 (Krom et al., 1991), leading to an ultra-oligotrophic state (Azov, 1991; Sisma-Ventura, Yam and

84 Shemesh, 2014; Hazan et al., 2018). The response of migrating species to these two simultaneous

85 and rapid processes (warming and elevated oligotrophy) is not well understood.

86 The introduction of the Indo-Pacific octocoral Melithaea erythraea Ehrenberg, 1834

87 (Alcyonacea: Melithaeidae) to the SEMS coast was first documented in 1999 within the Hadera

88 power plant harbor $\left(32.47^{\circ} \mathrm{N} / 34.88^{\circ} \mathrm{E}\right)$, where it was found in extremely high abundance, mostly

89 on artificial structures (20-80 colonies per $10 \mathrm{~m}$ line transect, Fine et al., 2005). However, in the

90 natural habitat of the Red Sea, this coral is rare, both on natural reefs and artificial structures, and

91 found mostly in shaded habitats on vertical reef walls, and in notches. This behavior is very similar

92 to other azooxanthellate that inhabit these niches uninhabited by zooxanthellate corals (Fabricius

93 and Alderslade, 2001). For example, the congeneric octocoral Melithaea biserialis Kükenthal,

941908 is found mostly in shaded habitats, on vertical reef walls of the Red Sea, and in high density

95 on artificial structures such as the oil jetty of Eilat (Zeevi-Ben Yosef and Benayahu, 1999). In

96 2015, colonies of M. erythraea were detected for the first time outside of the Hadera power plant

97 harbor in the rocky Nahsholim Bay at a depth of $3.5 \mathrm{~m}\left(32.61^{\circ} \mathrm{N} / 34.91^{\circ} \mathrm{E}\right.$, Fig. 1$)$. Those colonies

98 exhibited a 100\% genetic similarity to the M. erythraea Red Sea specimen (Grossowicz et al.,

99 2020). Further observations revealed a stable population along this coast comprising many

100 colonies, all in shaded locations on either vertical walls or in crevices (Grossowicz et al., 2020). 
101 Grossowicz et al. (2020) reported that M. erythraea is not yet invasive, however, its population

102 expansion may yet occur, due to a lag between initial introduction and population explosion (see

103 Rilov et al., 2004). They hypothesized that the gradual warming of surface water of the SEMS may

104 have contributed towards the survival of $M$. erythraea during the winter, and enabled this species

105 to expand beyond its distributional range. To date, M. biserialis has never been recorded in the

106 Mediterranean.

107 While reef-building stony corals (Scleractinia) form hard and massive aragonite skeletons,

108 octocorals produce spiny internal polycrystalline high-magnesium calcite skeletal elements that

109 are called sclerites, as well as a central axis (Cohen and McConnaughey, 2003; Taubner et al.,

110 2012; Fabricius and Alderslade, 2001). Sclerites are highly variable in shape, size, and articulation,

111 and differ substantially from one species to another. Therefore, these are an important trait in

112 octocoral taxonomy (Fabricius and Alderslade, 2001; Tentori and Ofwegen, 2011). Looking at the

113 skeletal characteristics and isotopic composition may provide insights in coral's ecophysiology

114 (Chaabane et al., 2016, 2019) and therefore may help us to understand the colonization of $M$.

115 erythraea along the SEMS, from a calcification point of view.

116 The morphological variability of a species' sclerites can be related to its geographical and

117 ecological environment, as was observed in several gorgonians [e.g., Pseudopterogorgia

118 elisabethae (Gutiérrez-Rodríguez et al., 2009), and Eunicea flexuosa (Prada et al., 2008)].

119 Variation in sclerite morphology may be altered in response to depth, water motion, light levels,

120 and environmental factors such as predation pressure (West, 1997). Morphological differences

121 may be a response to environmental factors (Rowley, 2018), but can also be attributed to

122 accumulated genetic differences, due to the disruption of gene flow among populations (Prada et

123 al., 2008). 
124 The sclerite calcification depends on the physiological traits of each octocoral and the

125 ambient environment (West, 1997). For example, a recent study has shown that the red octocoral

126 Corallium rubrum calcifcation is not $\mathrm{pH}$ upregulated with respect to the ambient seawater,

127 contrary to what is observed in scleractinians (Le Gof et al., 2017), making octocoral a highly

128 vulnerable species to enviromental changes, such as a decrease in seawater $\mathrm{pH}$. Growth rates of

129 corals, and octocorals in particular, are positively correlated with temperature (Chaabane et al.,

1302019 and references therein). Furthermore, temperature affects the sclerite deposition, as was

131 found in the cold-water octocoral Primnoa pacifica, where the magnesium/calcite ratio in the

132 sclerite was positively correlated to water temperature (Matsumoto, 2007).

133 In this study, we test the hypothesis that M. erythraea could survive in the Mediterranean

134 Sea due to warming of winter minimum temperatures. This hypothesis will be tested by analyzing

135 the sclerites' characteristics using scanned electron microscopy (SEM), carbon and oxygen stable

136 isotopes, and X-ray crystallography to understand, from a calcification perspective, the factors

137 which enabled M. erythraea to survive and establish a flourishing population in the SEMS.

\section{2. Methods}

140 2.1. Study site, temperature, coral collection and sclerite isolation

141 Specimens for SEM examination, crystallography, and carbon and oxygen stable isotope analysis

142 were collected from both the Mediterranean Sea and the Red Sea (Fig. 1). M. erythraea $1=$ iches

143 were collected during scuba dives in June 2016 and May 2017 in Nahsholim Bay. Samples from

144 Hadera port were collected in June 2016, and from Eilat (Red Sea), branches were collected in

145 May 2017. Branches from M. biserialis were also collected from Eilat in May 2017. From all 146 collected colonies, a branch from the distal parts of the colony was removed using scissors and 
147 preserved in absolute ethanol (96\%) prior to examination. For comparison, a specimen of $M$.

148 erythraea from Fine et al. (2005), collected in Hadera port, was examined as well (collected by Y.

149 Aluma in 2002 and stored in formalin at the Steinhardt Museum of Natural History, Israel National

150 Center for Biodiversity Studies, Tel Aviv, Israel).

151 Branches from each test colony were sub-sampled (1 $\mathrm{cm}$ in length). Sclerites were separated

152 from the soft tissue by placing each sub-sample in Eppendorf tubes filled with $10 \%$ sodium

153 hypochlorite until the soft tissue was dissolved. After $30 \mathrm{~min}$, the organic debris was removed, and

154 the sclerites were rinsed with distilled water several times to wash off the excess bleach and

155 supernatant. Multiple sclerites were ground to homogenous powders for later isotopic analysis.

156 Information of ambient conditions (temperature) was collected from Israel Oceanographic

157 and Limnological Research (IOLR) monitoring station in Hadera. For the period of 1994-2004,

158 temperature measurements were taken from a bottom-mounted Paroscientific-8DP060 ADCP. For

159 the period of 2004-2018, temperature measurements were taken from a bottom-mounted $600 \mathrm{kHz}$

160 WorkHorse Monitor ADCP. The ADCP was located at $11.6 \mathrm{~m}$ until 2004, then relocated to $26 \mathrm{~m}$

161 depth, southwest of the easternmost edge of the coal terminals in Hadera. The reported temperature

162 sensor precision is $\pm 0.4{ }^{\circ} \mathrm{C}$. The data series was curated for outliers, smoothed and binned.

163 All samples were collected under the permit from the Israel Nature and Parks Authority

164 (permit number: 2016-18/42200). Conducting the surveys in their areas was approved by Port of

165 Hadera Authority and Eilat-Ashqelon Pipe-Line Company.

166

$167 \quad 2.2 . \quad$ Isotope ratio mass-spectrometry (IRMS)

168 The fractionation of the oxygen isotopes into biogenic carbonates is a function of ambient 169 temperature and isotopic composition of the seawater at the time of their formation (Grossman and 
$170 \mathrm{Ku}, 1986$; McConnaughey, 1989a, b; Kim and O'Neil, 1997). If the isotopic ratio of ${ }^{16} \mathrm{O}$ and ${ }^{18} \mathrm{O}$

171 (expressed as $\delta^{18} \mathrm{O}$ ) of both calcium carbonate and water is known, the temperature at deposition

172 can be calculated. The isotopic fractionation of carbon $\left(\delta^{13} \mathrm{C}\right)$ in skeletal material provides

173 information about the organism's metabolism, as well as nutritional information (McConnaughey

174 et al., 1997) and, thus, can provide insights into the calcific response of migrating calcifying

175 species to severe oligotrophic conditions.

176 Stable isotope $\left(\delta^{18} \mathrm{O}\right.$ and $\left.\delta^{13} \mathrm{C}\right)$ measurements on bulk powders were performed at the stable isotope

177 laboratory of the Max-Planck Institute for Chemistry, Mainz, on a Thermo Delta V mass

178 spectrometer interfaced with a Gasbench preparation unit. Sample digestion took place on-line, in

$179>99 \%$ orthophosphoric acid, at $70{ }^{\circ} \mathrm{C}$. Coral samples were analyzed together with several calcite

180 standards, including the international standard IAEA603. The reproducibility of these routinely

181 analyzed in-house $\mathrm{CaCO}_{3}$ standards is typically greater than $0.1 \%$ (1SD) for both carbon and

182 oxygen isotope ratios. Both $\delta^{18} \mathrm{O}$ and $\delta^{13} \mathrm{C}$ of the sclerites are reported relative to the VPDB

183 standard scale.

184

185 2.3. Estimation of $\mathrm{CaCO}_{3} \underline{\text { depositional temperatures }}$

186 The oxygen isotope composition of biogenic $\mathrm{CaCO}_{3}$ is a function of ambient water temperature

187 and the $\delta^{18} \mathrm{O}$ of the seawater at the time of its formation and from this depositional temperatures

188 can be estimated (Grossman and Ku, 1986; Kim and O’Neil, 1997). The calcite temperature-

189 dependent fractionation during bio-mineralization is described by the equation of Friedman and 190 O'Neil (1977):

$$
10^{3} \ln \alpha_{\text {calcite }- \text { water }}=2.78\left(10^{6} / T^{2}\right)-2.89
$$


192 where $\alpha_{\text {calcite-water }}$ is the oxygen isotope fractionation factor between calcite and water (Eq. 2) and

$193 \mathrm{~T}$ is the water temperature $(\mathrm{K})$.

$$
\alpha_{\text {calcite-water }}=\left(10^{3}+\delta^{18} O_{\text {calcite }}\right) /\left(10^{3}+\delta^{18} O_{\text {water }}\right)
$$

194

195 The mean annual $\delta^{18} \mathrm{O}_{\mathrm{sw}}$ value of 1.6\% (Sisma-Ventura, Yam and Shemesh, 2014; Sisma-Ventura

196 et al., 2016) and 1.9\%o (Mizrachi et al., 2010) of surface water in the Mediterranean and the Gulf

197 of Aqaba, respectively, and the $\delta^{18} \mathrm{O}_{\mathrm{SC}}$ of $M$. erythraea from both habitats were used for the

198 calculation of deposition temperatures. It is noted that the $\delta^{18} \mathrm{O}_{\mathrm{sw}}$ in both the Mediterranean Sea

199 and the Gulf of Aqaba fluctuated by less than $0.5 \%$, annually. A combination of the analytical

200 uncertainties of $<0.5 \%$ for both measurements translates into uncertainty of $\sim 2{ }^{\circ} \mathrm{C}$ (i.e., $0.2 \%$ o ${ }^{\circ}$ $\left.201^{1}\right)$.

202

203 2.4. Estimation of percentage of metabolic carbon intake during calcification

204 We estimated the percentage of the metabolic carbon that contributed to $\delta^{13} \mathrm{C}_{\mathrm{SC}}$ using the mass 205 balance equation (McConnaughey et al., 1997):

$$
\delta^{13} C_{\text {calcite }}-\varepsilon_{\text {calcite - bicarbonate }}=M\left(\delta^{13} C_{F o o d}\right)+(1-M) \delta^{13} C_{D I C}
$$

206

207 where $\mathrm{M}$ is the percentage of the metabolic carbon contribution and $\varepsilon_{\text {calcite-bicarbonate }}$ is the 208 enrichment factor between calcite and bicarbonate (+1\%, Romanek, Grossman and Morse, 1992).

209 The $\delta^{13} \mathrm{C}$ of $M$. erythraea sclerites may indicate a food source (phytoplankton-small zoo-plankton;

210 Zeevi-Ben Yosef et al., 1999; $\delta^{13} \mathrm{C}=\sim-20 \%$ ), and DIC (1\%o; Mizrachi et al., 2010; Sisma-Ventura,

211 Yam and Shemesh, 2014; Sisma-Ventura et al., 2016) of both habitats were used to calculate the 212 metabolic contribution to the skeletal buildup. 
214 2.5. X-ray diffraction crystallography

215 Crystallinity is an important parameter of mineral aggregates such as skeletons. This property can

216 be effected by internal heterogeneity in the crystal, nucleation rate, protein framework structure,

$217 \mathrm{Sr}$ and $\mathrm{Mg}$ concentration and crystal growth rate and is, therefore, a useful parameter to understand

218 environmental effects expressed by in the calcification.

219 X-ray diffractometry (XRD) was used to evaluate the crystallinity of the sclerites. Full width at

220 high maximum (FWHM) of crystallinity level (Patterson, 1939) was calculated for the calcite's

$221 \mathrm{~d}_{104}$ peak following the Scherrer equation (Scherrer, 1918):

$$
\tau=\frac{K \lambda}{\beta \cos \theta}
$$

222 Where $\tau$ is the mean size of the ordered (crystalline) domains, $\lambda \mathrm{X}$-ray wavelength; $\mathrm{K}$ is the shape

223 factor; $\beta$ is FWHM and $\theta$ is the Bragg angle. As all parameters are constant other than the FWHM,

224 then $\tau$ is proportional to $\beta^{-1}$. Given that the shape factor could not be determined in most case,

225 FWHM can be used as an index to the level of crystallinity.

226 The analysis was conducted with a Rigaku MiniFlex benchtop XRD, with the sclerites deposited 227 from suspension on a custom slide and allowed to dry in a desiccator. Diffraction was carried out 228 from 10 to $75^{\circ}$ at $0.01^{\circ}$ steps at a rate of $2.15^{\circ}$ per minute.

229

230 2.6. Sclerite morphology and statistical analysis

231 The morphometric complexity of the sclerites was assessed by SEM analysis. Spindle-shaped

232 sclerites from all specimens were placed in non-coated high/low vacuum mode and were examined 233 and photographed with Jeol JCM-7000 NeoScope benchtop SEM with secondary electron and 
234 backscatter modes set to magnify at $\times 200$ and $\times 300$. From each specimen, $n=32-46$ sclerites (see

235 Table 1) were examined, and the measurements of the axes (length and width) were taken using

236 built-in software. In addition, along the longitudinal axis, warts were counted to obtain their

237 density. The number of warts was divided by axis length (in $\mu \mathrm{m}$ ).

238 Statistical analyses were performed under permutation concepts, non-parametric tests that analyze

239 quantified data that do not satisfy the assumptions underlying traditional parametric tests (e.g.,

240 normality, etc., Collingridge, 2013). To compare the effect of "site" (Nahsholim, Hadera, and

241 Eilat), and "axis" (long, short) on sclerite morphometrics, we performed a nested Permutation

242 ANOVA, followed by a pairwise permutation posthoc test. Before analysis, data were normalized.

243 Axes' ratio and wart density on sclerites among sites were examined with one-way Permutation

244 ANOVA, followed by pairwise permutation posthoc test. All values are presented at a confidence

245 interval of $95 \%$. All statistical and multivariate analyses were performed with R i386 3.3.3 (R Core

246 Team, 2014) using 'ImPerm' and 'rcompanion' packages.

247

\section{3. Results}

249 3.1. $\quad$ Sclerite morphometrics

250 The sclerites (shown in Fig. 2) captured in the SEM were mostly spindle shaped, a shape found in

251 all samples. In the Red Sea, we also observed a spheroidal shape (for both M. erythraea and $M$.

252 biserialis). The sclerites exhibited some visual differences between the sites. The Red Sea sclerites

253 looked thicker than the Mediterranean ones, and their wart density appear to be higher (see Table

254 1, raw measurement of the sclerites is provided in the Supp. Info.).

255 The sclerite axis characteristics were significantly different by size (Fig. 3A, Nested permutation

256 ANOVA, $p<0.001$ ), where posthoc pairwise comparisons suggested that the corals in the Red Sea 
257 have thicker sclerites in comparison with all other test corals collected in the Mediterranean (all

258 pairings with the Eilat specimen, except Eilat-Hadera 2002, are $p$-adjusted $<0.002$ ).

259 These differences are also reflected in the long-to-short axes ratio comparison (Fig. 3B,

260 Permutation ANOVA, $p<0.001)$, where the Red Sea sclerites had the smallest ratio $(3.19 \pm 1.15)$

261 compared to all other sites ( $4.78 \pm 1.18$, and $4.98 \pm 1.52$ in Nahsholim 2016 and 2017, respectively,

262 and $4.55 \pm 1.30,4.14 \pm 1.30$ in Hadera 2002 and 2016, $p$-adjusted $<0.005$ ), not including the $M$.

263 biserialis pair $(p$-adjusted $=0.39)$. M. biserialis' ratio $(3.58 \pm 2.23)$ was similar to both Hadera

264 (2002 and 2016) specimens ( $p$-adjusted $>0.2$ ) and was significantly different than all the other

265 sites ( $p$-adjusted $<0.02$ ). In addition, the Hadera 2016 sclerite axis ratio is significantly different

266 than those collected from Nahsholim ( $p$-adjusted $<0.05)$.

267 Warts along the sclerites' axis were counted to determine their density. The wart density differed 268 among the different sites (Fig. 3C, Permutation ANOVA, $p<0.001$ ), where the M. erythraea Red

269 Sea specimen has a significantly higher density $\left(0.057 \pm 0.013 \# \mu \mathrm{m}^{-1}\right)$ than those collected from 270 the Mediterranean $(0.049 \pm 0.006,0.051 \pm 0.007,0.0047 \pm 0.008$ in Nahsholim 2016-2017, and $2710.047 \pm 0.006$ and $0.049 \pm 0.006 \# \mu \mathrm{m}^{-1}$ in Hadera 2002 and 2016, respectively, $p$-adjusted $<0.05$ ), 272 except the pair collected from Eilat and Nahsholim 2017 ( $p$-adjusted $>0.1$ ).

273

274 3.2. $\quad \underline{\text { Isotopes }}$

275 The results in Fig. 4 summarize the $\delta^{18} \mathrm{O}_{\mathrm{SC}}$ and $\delta^{13} \mathrm{C}$ values of M. erythraea and M. biserialis 276 sclerites from the Gulf of Aqaba (Red Sea), and of M. erythraea from the Israeli coast (SEMS).

277 The $\delta^{18} \mathrm{O}_{\text {SC }}$ value of samples from the Gulf of Aqaba, which were collected during May 2017, 278 ranged between $0.33 \pm 0.045 \%$ in M. erythraea and $0.01 \pm 0.061 \%$ in M. biserialis (the average 279 temperature of deposition was $23{ }^{\circ} \mathrm{C}$ and $24.5 \pm 0.5{ }^{\circ} \mathrm{C}$, respectively). Similarly, M. erythraea 
280 samples from the Port of Hadera (the first documented colonization), was collected in the spring

281 of 2002, and yielded $\delta^{18} \mathrm{O}_{\mathrm{SC}}$ values between 0.26 and $0.4 \pm 0.063 \%$ (depositional temperatures of

$\left.28221 \pm 0.7^{\circ} \mathrm{C}\right)$. The $\delta^{18} \mathrm{O}_{\mathrm{SC}}$ values of samples collected during 2016 and 2017 in early spring from

283 Hadera and Nahsholim Bay ranged between $0.22 \pm 0.03$ and $0.36 \pm 0.052 \%$ (deposition

284 temperatures of $21.2 \pm 0.5^{\circ} \mathrm{C}$ ). The 2017 (early summer) samples from the Nahsholim Bay yielded

$285 \delta^{18} \mathrm{O}_{\mathrm{SC}}$ values of $1.07 \pm 0.05 \%$ (deposition temperatures of $27.7 \pm 0.4{ }^{\circ} \mathrm{C}$ ).

286 The samples from the Gulf of Aqaba (May 2017) yielded $\delta^{13} \mathrm{C}_{\mathrm{SC}}$ values ranging between $0.25 \pm$ 287 0.033\% (M. biserialis) and $-0.26 \pm 0.02 \%$ (M. erythraea), and those sampled from the Hadera 288 port in 2002 averaged $-0.38 \pm 0.1 \%$. The $\delta^{13} \mathrm{C}_{\mathrm{SC}}$ values of samples collected during 2016 and 2017 289 in early spring from Hadera and Nahsholim Bay ranged between $-1.38 \pm 0.062$ and $-1.16 \pm 0.12 \%$. 290 The 2017 early summer samples from the Nahsholim Bay yielded $\delta^{13} \mathrm{C}_{\mathrm{SC}}$ values, averaging -1.24 $291 \pm 0.18 \%$. Results are summarized in Table 1 and the 'Isotopes' section within the Supp. Info.

293 3.3. Crystallography

294 FWMH or the $\mathrm{d}_{104}$ peak of the calcites ranged from 0.10 to 0.27 with the $\mathrm{d}$ spacing ranging from 2952.988 to 2.997; peak asymmetry ranged from 0.56 to 2.8. The Eilat samples and 2002 Hadera 296 samples exhibit the lower values of asymmetry and d spacing values with the higher FWHM values 297 relative to the 2016 and 2017 values. The length of $\delta^{13} \mathrm{C}_{\mathrm{SC}}$ and the long axis are positively 298 correlated to FWMH (inversed to crystallinity, Table 1, Fig. 5).

299 3.4. Sea surface temperature (SST)

300 Mean SST in the coast of Hadera had not changed significantly since the early 1990's and remained 301 at $23.2 \pm 4.3{ }^{\circ} \mathrm{C}(\mathrm{n}=199229)$. However, this figure is misleading as the extreme temperatures have

302 shifted in both summer and winter (Fig. 6). Notably, minima temperature ( $10^{\text {th }}$ percentile) has 
303 increased by $\sim 2{ }^{\circ} \mathrm{C}$ while maxima temperature $\left(90^{\text {th }}\right.$ percentile) has diminished by $\sim 1^{\circ} \mathrm{C}$. In

304 addition, the fractional time during which temperature was below $18^{\circ} \mathrm{C}\left(1994\right.$ 's $20^{\text {th }}$ percentile)

305 has diminished from $\sim 18 \%$ in 1994 to less than $5 \%$ in 2019 , while the fraction above $28^{\circ} \mathrm{C}(1994$ 's

$30680^{\text {th }}$ percentile) has diminished from $\sim 24 \%$ in 1994 to $\sim 15 \%$ in 2019 .

307

308 4. Discussion

309 Within the last few decades, the effects of anthropogenic global warming have become more

310 pronounced, to the point they can no longer be ignored or attributed to natural processes (Weart,

311 2009). One of these effects is the opening of previously unavailable geographical niches to

312 invasive species (Bianchi and Morri, 2003). This is expressed most intensively in areas

313 experiencing extreme warming, such as higher latitudes (Stachowicz et al., 2002), although similar

314 processes also occur in some lower latitude domains such as the SEMS (Rilov and Galil, 2009).

315 Overall, the Levantine Sea has experienced warming of between $\sim 0.02$ (Sisma-Venture, Yam and

316 Shemesh, 2014; Marbà et al., 2015) to $\sim 1.0^{\circ} \mathrm{C} \mathrm{yr}^{-1}$ (Ozer et al., 2016), with the highest rates of

317 warming in the last few decades. This shift has also modified the coastal water's minimum winter

318 temperatures, which have risen from $\sim 16$ to $\sim 18^{\circ} \mathrm{C}$ since the 1990 s (Ozer et al., 2016).

319 As was observed in several gorgonian species, the variation in morphological features is also

320 related to the geographical environment (Gutiérrez-Rodríguez et al., 2009; Prada et al., 2008).

321 Octocoral sclerite deposition is dependent on the octocoral's physiological traits, and

322 environmental parameters such as temperature (West, 1997). The growth rate and deposition of

323 the skeletal elements of octocorals and other calcifiers, such as coralline algae, is correlated with

324 temperature (Crabbe, 2008; Matsumoto, 2007; Chaabane et al. 2019; Vielzeuf et al., 2013), and

325 therefore, we believe that upon migration, $M$. erythraea was subject to environmentally-related 
326 physiological changes to their sclerite deposition. Sclerite morphology shows that the M. erythraea

327 Red Sea specimens are thicker (lower long-to-short axes ratio) with increased wart density in

328 comparison with the Mediterranean conspecific. Furthermore, the specimen from Hadera collected

329 in 2002 may be in a transition state between the recent Mediterranean Sea collections and those

330 from the Red Sea. However, the port of Hadera is a confined body of water influenced by its power

331 plant water discharge and is by no means representative of the natural environment of $M$.

332 erythraea.

333 The $\delta^{18} \mathrm{O}_{\mathrm{SC}}$ values of M. erythraea collected along the SEMS coast during late winter and

334 early spring and summer yielded depositional temperatures between 21 and $28{ }^{\circ} \mathrm{C}$, respectively.

335 These temperatures match the depositional temperature range of its original habitat in the Red Sea

336 (Al-Rousan et al., 2007; Mizrachi et al., 2010) and those measured in the native specimens. Thus,

337 the hypothesis that the recent warming of the SEMS by $\sim 1.0^{\circ} \mathrm{C}$ decade-1 over the last 30 years

338 (Ozer et al., 2016) has enabled the octocoral M. erythraea to successfully colonize the area is

339 supported. Despite not having any M. erythraea samples during the maximum winter temperatures,

340 our bulk $\delta^{18} \mathrm{O}_{\mathrm{SC}}$ values, integrating multiple sclerites, indicate a preferential warm water

341 calcification of M. erythraea, and further support that the warming of the SEMS surface water is

342 a key factor for its successful migration. This assumption is further supported by the preferential

343 warm water calcification of endemic SEMS species, such as the reef building gastropods

344 Dendropoma petraeum complex (Dendropoma spp.) and Vermetus triquetrus (Sisma-Ventura,

345 Yam and Shemesh, 2014).

346 Stable isotope analysis of C. rubrum showed that both $\delta^{18} \mathrm{O}$ and $\delta^{13} \mathrm{C}$ are strongly influenced

347 by kinetic vital effects, which impede the direct extraction of temperature time-series

348 reconstructions for cold water octocoral (Chaabane et al., 2016). However, the results of the study 
349 by Chaabane et al. (2016) also show that at higher temperatures, octocoral's calcification 350 approaches temperature-dependent equilibrium fractionation, and is less likely affected by vital

351 effects, as is the case for other Mediterranean warm water calcifiers (Sisma-Venture et al., 2009;

352 Sisma-Ventura, Yam and Shemesh, 2014). Moreover, while high intra- and inter-annual variations

353 of $\mathrm{Mg} / \mathrm{Ca}$ were observed in the high-resolution profiles of sclerites of the Mediterranean $C$.

354 rubrum, the mean $\mathrm{Mg} / \mathrm{Ca}$ composition enabled good estimates of palaeoseawater temperature

355 (Chaabane et al., 2019). Similarly, our approach of using bulk powders, integrating multiple

356 sclerites may have reduced the isotopic shifts resulting from the vital effects.

357 Further, by analyzing time series SST data measured at the monitoring station in Hadera

358 port, we show that the lower $10^{\text {th }}$ percentiles of temperatures (winter minimum temperatures) have

359 increased by almost $2{ }^{\circ} \mathrm{C}$ (Fig. 6) over the last three decades. Thus, the warming of the winter

360 minimum temperatures of the SEMS is gradually expanding the time-frame of favorable

361 conditions for the introduction of tropical species.

362 While recent warming has provided the threshold conditions for the long-term colonization

363 of M. erythraea, it is also accompanied by an increase in oligotrophic conditions (Azov, 1991;

364 Sisma-Ventura, Yam and Shemesh, 2014; Ozer et al., 2016). However, it is difficult to capture the

365 effect of the changes in trophic level on the isotopic ratio of the migrating M. erythraea. We

366 assume that this factor may impose yet another limitation/stress to the migrating octocoral, which

367 is not likely to be distinguished by the $\delta^{13} \mathrm{C}_{\mathrm{SC}}$ values, since this limitation may be only secondary

368 to the thermal effect that can trigger periods of rapid growth, resulting in larger metabolic intake

369 during calcification (McConnaughey, 1989a, b; Klein et al., 1996; Lorrain et al., 2004).

370 Nevertheless, the most pronounced modification to the isotopic signal between the present SEMS

371 population and the Red Sea population was observed in the $\delta^{13} \mathrm{C}_{\mathrm{SC}}$ values. We recorded a mean 
372 offset of $-1.26 \%$ in $\delta^{13} \mathrm{C}_{\mathrm{SC}}$, between the M. erythraea Red Sea samples $\left(\delta^{13} \mathrm{C}\right.$ values between -0.28

373 and $0.30 \%$, representing $8.5 \%$ of metabolic carbon) and the samples collected from the SEMS

374 coast in 2016 and $2017\left(\delta^{13} \mathrm{C}\right.$ values between -1.07 and $-1.42 \%$, representing 15.4 to $17.1 \%$ of

375 metabolic carbon). Interestingly, the $2002 \delta^{13} \mathrm{C}_{\mathrm{SC}}$ value of $-0.38 \%$ (representing $11.9 \%$ of

376 metabolic carbon) from Hadera (SEMS) does not show this level of modification but rather showed

377 an intermediate value between the recent SEMS and M. erythraea Red Sea specimens.

378 This modification toward isotopic disequilibrium is common in biological carbonates and is

379 best described by two possible effects: the first is a kinetic effect and the second is a metabolic

380 effect. A kinetic isotope effect, which modulates both the carbon and oxygen isotopic composition

381 simultaneously (McConnaughey, 1989a; Maier, Pätzold and Bak, 2003), is a known factor that

382 influences the $\delta^{18} \mathrm{O}_{\mathrm{SC}}$ and $\delta^{13} \mathrm{C}_{\mathrm{SC}}$ values of cold water octocoral, such as the Mediterranean $C$.

383 rubrum (Chaabane et al. 2016). Here, kinetic isotopic effects seem less likely to have been

384 affecting the M. erythraea bulk skeletal isotopic composition. This is based on the samples of

3852016 , that show a wide range of $\delta^{18} \mathrm{O}_{\mathrm{SC}}$ values, between 0.21 (Hadera) and -1.07\% (Nahsholim),

386 while the $\delta^{13} \mathrm{C}_{\mathrm{SC}}$ values were merely unchanged $(-1.31 \pm 0.14 \%$, Hadera and Nahsholim). A

387 metabolic isotope effect, which modulates only the carbon isotopic composition (McConnaughey,

388 1989a), could thus explain the lower $\delta^{13} \mathrm{C}$ values of the M. erythraea in the SEMS compared to

389 the specimens in their native environment. Moreover, the metabolic isotope effect of M. erythraea

390 could be related to respiration, which leads to the incorporation of isotopically-depleted metabolic

391 carbon during sclerite deposition (McConnaughey et al., 1997). This is because respiration

392 enriches the internal DIC pool from which the skeleton is precipitated with ${ }^{12} \mathrm{C}$.

393 Other factors influencing the $\delta^{13} \mathrm{C}_{\mathrm{SC}}$-like changes in diet or the ambient $\delta^{13} \mathrm{C}_{\mathrm{DIC}}$ range

394 between the two habitats can be ruled out. The soft tissues $\delta^{13} \mathrm{C}$ and $\delta^{15} \mathrm{~N}$ values of both native and 
395 introduced species (Grossowicz et al., 2020) are similar, indicating no significant change in diet.

396 Furthermore, the ambient $\delta^{13} \mathrm{C}_{\mathrm{DIC}}$ range in both habitats is very similar (Mizrachi et al., 2010;

397 Sisma-Ventura, Yam and Shemesh, 2014; Sisma-Ventura et al., 2016). Thus, the change in $\delta^{13} C_{S C}$

398 of the sclerites should be in the fraction of metabolic carbon incorporate during calcification. The

399 observed increase in metabolic carbon fraction may result from rapid skeletal growth

400 (McConnaughey, 1989a, b; Klein et al., 1996; Lorrain et al., 2004; Chaabane et al. 2016; 2019),

401 or through ontogenetic effects (McConnaughey and Gillikin, 2008), which are both known to occur

402 in warm water. Exposure to more stressful conditions may also explain the observed changes, as

403 was suggested for the Mediterranean cold-water octocoral (Vielzeuf et al., 2013).

404 Interestingly, the modification in the $\delta^{13} \mathrm{C}_{\mathrm{SC}}$ is associated with crystals becoming larger in

405 the 2016-2018 population relative to that of 2002 and those in Eilat. Crystal size suggests that less

406 carbonate is precipitated in the SEMS specimens. This is also reflected by the higher wart density

407 and axes sizes of the Red Sea samples, compared to those from the Mediterranean ( $p$-adjusted $<$

408 0.05). Keeping in mind that the SEMS is an ultra-oligotrophic region, these changes in the sclerites

409 might be due to calcification under more stressful conditions, resulting from a preference for

410 warmer water and rapid skeletal growth, and increased incorporation of metabolic carbon, as was

411 found in the reef-building gastropods D. petraeum complex (Sisma-Ventura, Yam and Shemesh, 412 2014).

413

\section{5. Conclusions}

415 Our results suggest that the increase of minimum winter temperatures, which is a regional 416 manifestation of global climate change (Sisma-Ventura, Yam and Shemesh, 2014; Amitai et al., 417 2020), enabled the successful colonization and recent spreading of tropical M. erythraea 
418 populations along the SEMS coast, by prolonging the thermally favorable calcification season.

419 This study shows, for the first time, the response of the introduced soft coral M. erythraea to the

420 SEMS, a fast-warming and ultra-oligotrophic environment. This observation is part of the overall

421 story of "tropicalization" of the Mediterranean, and it provides insight into how species migrate

422 and colonize under the combined effects of warming surface oceans and increased oligotrophy,

423 driven by global climate change.

424

425

\section{Acknowledgments}

We would like to thank Dr Yaniv Aluma from Tel Aviv University and Prof. Maoz Fine from the

Interuniversity Institute for Marine Sciences in Eilat, Israel, for advising on coral location and

presence in the port; Tal Ozer from IOLR for access to raw temperature data; Dr Revital Ben

David-Zaslow from the Steinhardt Museum of Natural History, Israel National Center for

Biodiversity Studies, Tel Aviv, Israel, for M. erythraea specimens; Prof. Yehuda Benayahu from

Tel Aviv University and Dr Tali Mass from University of Haifa for fruitful discussion; Eitan

Maharam (Northern Wind Diving Center, Nahsholim, Israel), Dr Ateret Shabtay (Technion,

Israel), Hagai Nativ, and Ziv Zemah-Shamir (University of Haifa, Israel) for diving support; and

Leigh Livne for English editing.

\section{References}

Amitai Y., Yam R., Montagna P., Devoti S., López Correa M., Shemesh A. (2020). Spatial and temporal variability in Mediterranean climate over the last millennium from vermetid isotope records and CMIP5/PMIP3 models. Global and Planetary Change 189: 103159, doi:10.1016/j.gloplacha.2020.103159

439

441 Azov Y. (1991). Eastern Mediterranean - a marine desert? Marine Pollution Bulletin 23: 225$442 \quad 232$ 
443

444

445

446

447

448

449

450

451

452

453

454

455

456

457

458

459

460

461

462

463

464

465

466

467

468

469

470

471

472

473

474

475

476

477

478

479

480

481

482

483

484

485

486

487

488

Al-Rousan S., Felis T., Manasrah R., Al-Horani, F. (2007). Seasonal variations in the stable oxygen isotopic composition in Porites corals from the northern Gulf of Aqaba, Red Sea. Geochemical Journal, 41(5): 333-340

Béthoux J.P., Gentili B., Morin P., Nicolas E., Pierre C., Ruiz-Pino D. (1999). The Mediterranean Sea: a miniature ocean for climatic and environmental studies and a key for the climatic functioning of the North Atlantic. Progress in Oceanography, 44: 131146

Bianchi C.N., Morri C. (2003). Global sea warming and 'tropicalization' of the Mediterranean Sea: biogeographic and ecological aspects. Biogeographia, 24: 319-327

Bialik O.M., Sisma-Ventura G. (2016). Proxy-based reconstruction of surface water acidification and carbonate saturation of the Levant Sea during the Antropocene. Antropocene, 16: 4253

Burrows M.T., Schoeman D.S., Buckley L.B., Moore P., Poloczanska E.S., Brander K.M., Brown C., Bruno J.F., Duarte C.M., Halpern B.S., Holding J., Kappel C.V., Kiessling W., O’Connor M.I., Pandolfi J.M., Parmesan C., Schwing F.B., Sydeman W.J., Richardson A.J. (2011). The pace of shifting climate in marine and terrestrial ecosystems. Science, 334(6056): 652-655

Chaabane S., López Correa M., Ziveri P., Trotter J., Kallel N., Douville E., McCulloch M., Taviani M., Linares C., Montagna P. (2019). Elemental systematics of the calcitic skeleton of Corallium rubrum and implications for the $\mathrm{Mg} / \mathrm{Ca}$ temperature proxy. Chemical Geology, 524: 237-258; doi:10.1016/j.chemgeo.2019.06.008

Chaabane S., López Correa M., Montagna P., Kallel N., Taviani M., Linares C., Ziveri P. (2016). Exploring the oxygen and carbon isotopic composition of the Mediterranean red coral (Corallium rubrum) for seawater temperature reconstruction. Marine Chemistry, 186: 1123; doi:10.1016/j.marchem.2016.07.001.

Chevaldonné P., Lejeusne C. (2003). Regional warming-induced species shift in north-west Mediterranean caves. Ecological Letters, 6: 371-379

Cohen A.L., McConnaughey T.A. (2003). Geochemical perspectives on coral mineralization. Reviews in mineralogy and geochemistry, 54(1): 151-187

Collingridge D.S. (2013). A Primer on quantitized data analysis and permutation testing. Journal of Mix Methods Research 7(1): 79-95. doi:10.1177/1558689812454457

Crabbe M.J.C. (2008). Climate change, global warming and coral reefs: Modelling the effects of temperature. Computational Biology and Chemistry, 32: 311-314

Ehrenfeld, J.G. (2010). Ecosystem consequences of biological invasions. Annual Review of Ecology, Evolution, and Systematics, 41: 59-80, doi: 10.1146/annurev-ecolsys-102209144650

Fabricius K., Alderslade P. (2001). Soft corals and sea fans: a comprehensive guide to the tropical shallow water genera of the central-west Pacific, the Indian Ocean and the Red Sea. Australian Institute of Marine Science and the Museum and Art Gallery of the Northern Territory

Fine M., Aluma Y., Meroz-Fine E., Abelson A., Loya Y. (2005). Acabaria erythraea (Octocorallia : Gorgonacea) a successful invader to the Mediterranean Sea? Coral Reefs, 24:161-164

Friedman I., O'Neil J.R. (1977). Compilation of stable isotope fractionation factors of geochemical interest, in: M. Fleischer (ed.), Data of Geochemistry, pp. 1-12, U.S. Gov. Print. Off., Washington D.C.

Peer] reviewing PDF | (2020:02:45922:1:1:NEW 15 May 2020) 
489

490

491

492

493

494

495

496

497

498

499

500

501

502

503

504

505

506

507

508

509

510

511

512

513

514

515

516

517

518

519

520

521

522

523

524

525

526

527

528

529

530

531

Grossowicz M., Shemesh E., Martinez S., Benayahu Y., Tchernov D. (2020). New evidence of Melithaea erythraea colonization in the Mediterranean. Estuarine, Coastal and Shelf Science, 236, doi: 1 i.j $016 /$ j.ecss.2020.106652

Grossman E.L., Ku T.-L. (1986). Oxygen and carbon isotope fractionation in biogenic aragonite: Temperature effects. Chemical Geology, 59: 59-74

Gutiérrez-Rodríguez C., Barbeitos M.S., Sánchez J.A., Lasker H.R. (2009). Phylogeography and morphological variation of the branching octocoral Pseudopterogorgia elisabethae. Molecular Phylogenetics and Evolution, 50: 1-15

Hazan, O., Silverman, J., Sisma-Ventura, G., Ozer, T., Gertman, I., Shoham-Frider, E., Kress, N., Rahav, E. (2018). Mesopelagic prokaryotes alter surface phytoplankton production during simulated deep mixing experiments in Eastern Mediterranean Sea waters. Frontiers in Marine Sciences, 5: 1.

Hewitt C.L., Hayes K.R. (2002). Risk assessment of marine biological invasions. In: Leppäkoski E, Gollasch S., Olenin S. (eds.), Invasive aquatic species of Europe, distribution, impacts and management, pp. 456-466. Dordrecht: Kluwer Academic Publishers

Jordà G., Marbà N., Duarte C.M. (2012). Mediterranean seagrass vulnerable to regional climate warming. Nature Climate Change, 2: 821-824

Kim S.T., O'Neil, J.R. (1997). Equilibrium and nonequilibrium oxygen isotope effects in synthetic carbonates. Geochimica et Cosmochimica Acta, 61: 3461-3475.

Klein R.T., Lohmann K.C., Thayer C.W. (1996). Sr/Ca and ${ }^{13} \mathrm{C} /{ }^{12} \mathrm{C}$ ratios in skeletal calcite of Mytilus trossulus: covariation with metabolic rate, salinity, and carbon isotopic composition of seawater. Geochimica et Cosmochimica Acta, 60: 4207-4221

Krom M.D., Kress N., Brenner S., Gordon L.I. (1991). Phosphorus limitation of primary productivity in the eastern Mediterranean Sea. Limnology and Oceanography, 36: 424-432

Kükenthal W.G. (1913). Alcyonaria des Roten Meeres. K. k. Hof-u. Staatsdr., Hölder.

Le Goff C., Tambutté E., Venn A.A., Techer N., Allemand D., Tambutté S. (2017). In vivo pH measurement at the site of calcification in an octocoral. Scientific Reports, 7: 11210; doi:10.1038/s41598-017-10348-4

Lea D.W. (2003). Elemental and isotopic proxies of past ocean temperatures. In: Holland H.D. and Turekian K.K. (eds.). The ocean and marine geochemistry, vol. 6: Treatise on geochemistry, pp. 365-390, Elsevier Pergamon, Oxford

Lejeusne C., Chevaldonné P., Pergent-Martini C., Boudouresque C.F., Pérez T. (2009). Climate change effects on a miniature ocean: the highly diverse, highly impacted Mediterranean Sea. Trends in Ecology and Evolution, 25: 250-260

Lorrain A., Paulet Y.M., Chauvaud L., Dunbar R., Mucciarone D., Fontugne, M. (2004). $\delta^{13} \mathrm{C}$ variation in scallop shells: increasing metabolic carbon contribution with body size? Geochimica et Cosmochimica Acta, 68(17): 3509-3519

Ludwig W., Dumont E., Meybeck M., Heussner S. (2009). River discharges of water and nutrients to the Mediterranean Sea: Major drivers for ecosystem changes during past and future decades? Progress in Oceanography, 80: 199- 217

Mack R.N., Simberloff D., Lonsdale W.M., Evans H., Clout M., Bazzaz F.A. (2000). Biotic invasions: causes, epidemiology, global consequences, and control. Ecological Applications, 10: 689-710 
532

533

534

535

536

537

538

539

540

541

542

543

544

545

546

547

548

549

550

551

552

553

554

555

556

557

558

559

560

561

562

563

564

565

566

567

568

569

570

571

572

573

574

575

576

Marbà N., Jorda G., Agusti S., Girard C., Duarte C.M. (2015). Footprints of climate 676 change on Mediterranean Sea biota. Frontiers in Marine Science, 2: 56, doi:10.3389/fmars.2015.00056

Matsumoto A.K. (2007). Effects of low water temperature on growth and magnesium carbonate concentrations in the cold-water gorgonian Primnoa pacifica. Bulletin of Marine Science, 81(3): 423-435

McConnaughey T. (1989a). ${ }^{13} \mathrm{C}$ and ${ }^{18} \mathrm{O}$ isotopic disequilibrium in biological carbonates: I. Patterns. Geochimica et Cosmochimica Acta, 53, 151-162

McConnaughey T. (1989b). ${ }^{13} \mathrm{C}$ and ${ }^{18} \mathrm{O}$ isotopic disequilibrium in biological carbonates: II. In vitro simulation of kinetic isotope effects. Geochimica et Cosmochimica Acta, 53, 163171

McConnaughey T.A., Burdett J., Whelan J.F., Paull C.K. (1997). Carbon isotopes in 946 biological carbonates: Respiration and photosynthesis. Geochimica et Cosmochimica Acta, 61: 611-622

McConnaughey T.A., Gillikin D.P. (2008). Carbon isotopes in mollusk shell carbonates. GeoMarine Letters, 28(5-6): 287-299

Maier C., Pätzold J., Bak R.P.M. (2003). The skeletal isotopic composition as an indicator of ecological and physiological plasticity in the coral genus Madracis. Coral Reefs 22: 370380

Mizrachi I., Loya Y., Rosenfeld M., Kramarski-Winter E., Yam R., Shemesh A. (2010). The buildup of the isotopic signal in skeletons of the stony coral Porites lutea, Geochimica et Cosmochimica Acta, 74: 7021-7030

Ozer T., Gertman, I., Kress, N., Silverman J., Barak Herut, B. (2016). Interannual thermohaline (1979-2014) and nutrient (2002-2014) dynamics in the Levantine surface and intermediate water masses, SE Mediterranean Sea. Global Planetary Change, 151: 60-67. doi:10.1016/j.gloplacha.2016.04.001

Patterson A.L. (1939). The Scherrer formula for X-ray particle size determination. Physical Review, 56(10): 978-982

Prada C., Schizas N.V., Yoshioka P.M. (2008). Phenotypic plasti itu or speciation? A case from a clonal marine organism. BMC Evolutionary Biology, dc.1186/1471-2148-8- 47

QGIS Team Q.D. (2016). QGIS geographic information system. Open source geospatial foundation project.

R Core Team (2014). R: A Language and Environment for Statistical Computing. Vienna: R Foundation for Statistical Computing.

Raitsos D.E., Beaugrand G., Georgopoulos D., Zenetos A., Pancucci-Papadopoulou M.A., Teocharis A., Papathanassiou E. (2010). Global climate change amplifies the entry of tropical species into the Mediterranean Sea. Limnology and Oceanography, 55(4): 14781484

Rilov G., Benayahu Y., Gasith A. (2004). Prolonged lag in population outbreak of an invasive mussel: a shifting-habitat model. Biological Invasions 6 (3): 347-364

Rilov G. (2016). Multi-species collapses at the warm edge of a warming sea. Scientific Reports, 6,36897

Rilov G., Galil B. (2009). Marine bioinvasions in the Mediterranean Sea-history, distribution and ecology. In: G. Rilov and J. A. Crooks (eds.), Biological invasions in marine ecosystems, pp. 549-575. Berlin: Springer-Verlag 
577

578

579

580

581

582

583

584

585

586

587

588

589

590

591

592

593

594

595

596

597

598

599

600

601

602

603

604

605

606

607

608

609

610

611

612

613

614

615

616

617

618

619

620

621

622

Romanek C.S., Grossman E.L., Morse J.W. (1992). Carbon isotopic fractionation in synthetic aragonite and calcite: Effects of temperature and precipitation rate. Geochimica et Cosmochimica Acta, 56: 419-430

Rowley SJ. (2018). Acclimatory capacity of the Gorgonian Isis hippuris Linnaeus, 1758 to environmental change in SE Sulawesi, Indonesia. Journal of Experimental Marine Biology and Ecology. 500: 73-88. DOI:org/10.1016/j.jembe.2017.12.012

Scherrer P. (1918). Bestimmung der Größe und der inneren Struktur von Kolloidteilchen mittels Röntgenstrahlen." Nachrichten von der Gesellschaft der Wissenschaften zu Göttingen, Mathematisch-Physikalische Klasse, 2: 98-100

Sisma-Ventura G., Yam R., Shemesh A. (2014). Recent unprecedented warming and oligotrophy of the eastern Mediterranean Sea within the last millennium. Geophysical Research Letters, doi: 10.1002/2014GL060393

Sisma-Ventura G., Yam R., Kress N., Shemesh A. (2016). Water column distribution of stable isotopes and carbonate properties in the South-eastern Levantine basin (Eastern Mediterranean): Vertical and temporal change, Journal of Marine System, doi:10.1016/j.jmarsys.2016.01.012

Sisma-Ventura G., Bialik O.M., Yam R., Herut B., Silverman J. (2017). $p \mathrm{CO}_{2}$ variability and air-sea $\mathrm{CO}_{2}$ fluxes in the ultra-oligotrophic, South-East Levantine basin, Marine Chemistry, $\mathrm{d} \div \mathrm{T}$ 10.1016/j.marchem.2017.06.006

Stachowicz J.J., Terwin J.R., Whitlatch R.B., Osman R.W. (2002). Linking climate change and biological invasions: ocean warming facilitates non-indigenous species invasions. Proceeding of the National Academy of Sciences USA, 99:15497-15500

Taubner I., Böhm F., Eisenhauer A., Garbe-Schönberg D., Erez J. (2012). Uptake of alkaline earth metals in Alcyonarian spicules (Octocorallia). Geochimica et Cosmochimica Acta, 84: $239-255$

Tentori E, van Ofwegen L.P. (2011). Patterns of distribution of calcite crystals in soft coral sclerites. Journal of Morphology, 272: 614-628

Theoharides K.A., Dukes J.S. (2007). Plant invasion across space and time: factors affecting nonindigenous species success during four stages of invasion. New Phytologist, 176: $256-273$.

United States Department of Commerce National Oceanic and Atmospheric Administration National Geophysical Data Center (2001). 2-Minute gridded global relief data (ETOPO2).

Vielzeuf D., Gagnon A.C., Ricolleau A., Devidal J.-L., Balme-Heuze C., Yahiaou N., Fonquernie C., Perrin J., Garrabou J., Montel J.-M., Floquet N. (2018). Growth kinetics and distribution of trace elements in precious corals. Frontiers in Earth Science, 6: 167; doi:10.3389/feart.2018.00167

Weart S.R. (2009). The Discovery of Global Warming, Harvard University press

West J.M., (1997). Plasticity in the sclerites of a gorgonian coral: tests of water motion, light level, and damage cues. Biological Bullatine 192: 279-289

Zeevi-Ben Yosef D., Benayahu Y. (1999). The gorgonian coral Acabaria biserialis: life history of a successful colonizer of artificial substrata. Marine Biology 135(3): 473-481

Figure and table legends

Peer] reviewing PDF | (2020:02:45922:1:1:NEW 15 May 2020) 
623 Fig. 1. Map of the study area and collection sites along the SEMS coast (Hadera and Nahsholim, 624 M. erythraea) and the Red Sea, Gulf of Aqaba (Eilat, M. erythraea and M. biserialis). Note the 625 current annual SST range in the SEMS and the northern Red Sea (Tel Aviv and Aqaba, respectively). Maps were created using QGIS (QGIS Team, 2016), and ETOPO2 (NOAA, 2001) was used as a base layer.

Fig. 2. M. erythraea and M. biserialis sclerite morphology. (A) Spindles and spheroid of $M$. erythraea from Eilat (2017); (B) spindles and spheroid of M. biserialis from Eilat (2017); (C) spindles of M. erythraea from Hadera (2016); (D) spindles of M. erythraea from Hadera (2002); and (E) spindles of M. erythraea from Nahsholim (2016). Please note the thicker and denser warts of the Red Sea sclerites with respect to the slender Mediterranean counterparts.

634 Information on the coral sclerites can be found in Kükenthal (1913).

635

636

637

Fig. 3. Sclerite morphometrics. (A) Comparison of sclerite width and length from the different sites; (B) Sclerites length-to-width ratio at the different sites; and (C) Wart density along the main sclerites axes at the different sites. $\mathrm{Na}$ - Nahsholim, Ha-Hadera.

639

640

641

Fig. 4. Cross plot of $\delta^{13} \mathrm{C}$ derived metabolic carbon (Eq. 3) and $\delta^{18} \mathrm{O}$ derived temperature (Eq. 1) of sclerite deposition of Melithaea erythraea. The mean offset of $-1.26 \%$ in $\delta^{13} \mathrm{C}_{\mathrm{SC}}$ between the Red Sea samples ( $\delta^{13} \mathrm{C}$ values between -0.28 and $0.30 \%$ ) and the samples collected from the SEMS coast in 2016 and 2017 ( $\delta^{13} \mathrm{C}$ values between -1.07 and $-1.42 \%$ ), represent an increase of $\sim 50 \%$ in metabolic carbon intake during calcification. The $2002 \delta^{13} \mathrm{C}_{\mathrm{SC}}$ value of $0.38 \%$ from Hadera (SEMS) shows an intermediate value between the recent SEMS and Red Sea specimens.

647

Fig. 5. Relation of the M. erythraea sclerite morphometry (length of the long axis) to (A) its full width at half maximum (FWHM) of the calcite [104] peak and (B) $\delta^{13} \mathrm{C}$ values of the bulk sclerites for each year.

651

652

653

654

655

656

Fig. 6. Variation in sea surface temperature of the Israeli coast (Hadera monitoring station time series, 1994 to 2018). (A) Stacked annual histograms, the red line traces the lower $10^{\text {th }}$ percentile; (B) Fitted trendline of recorded temperature illustrates the increased warming of water during winters (annually, for the lower 10th percentile).

Table 1. Summary table of morphometrics, stable isotopic data, and crystallography. Detailed results can be found in the Supp. Info.

659

660 
Figure 1

Map of the study area and collection sites along the SEMS coast (Hadera and Nahsholim, M. erythraea) and the Red Sea, Gulf of Aqaba (Eilat, M. erythraea and M. biserialis).

Note the current annual SST range in the SEMS and the northern Red Sea (Tel Aviv and Aqaba, respectively). Maps were created using QGIS (QGIS Team, 2016), and ETOPO2 (NOAA, 2001) was used as a base layer. 


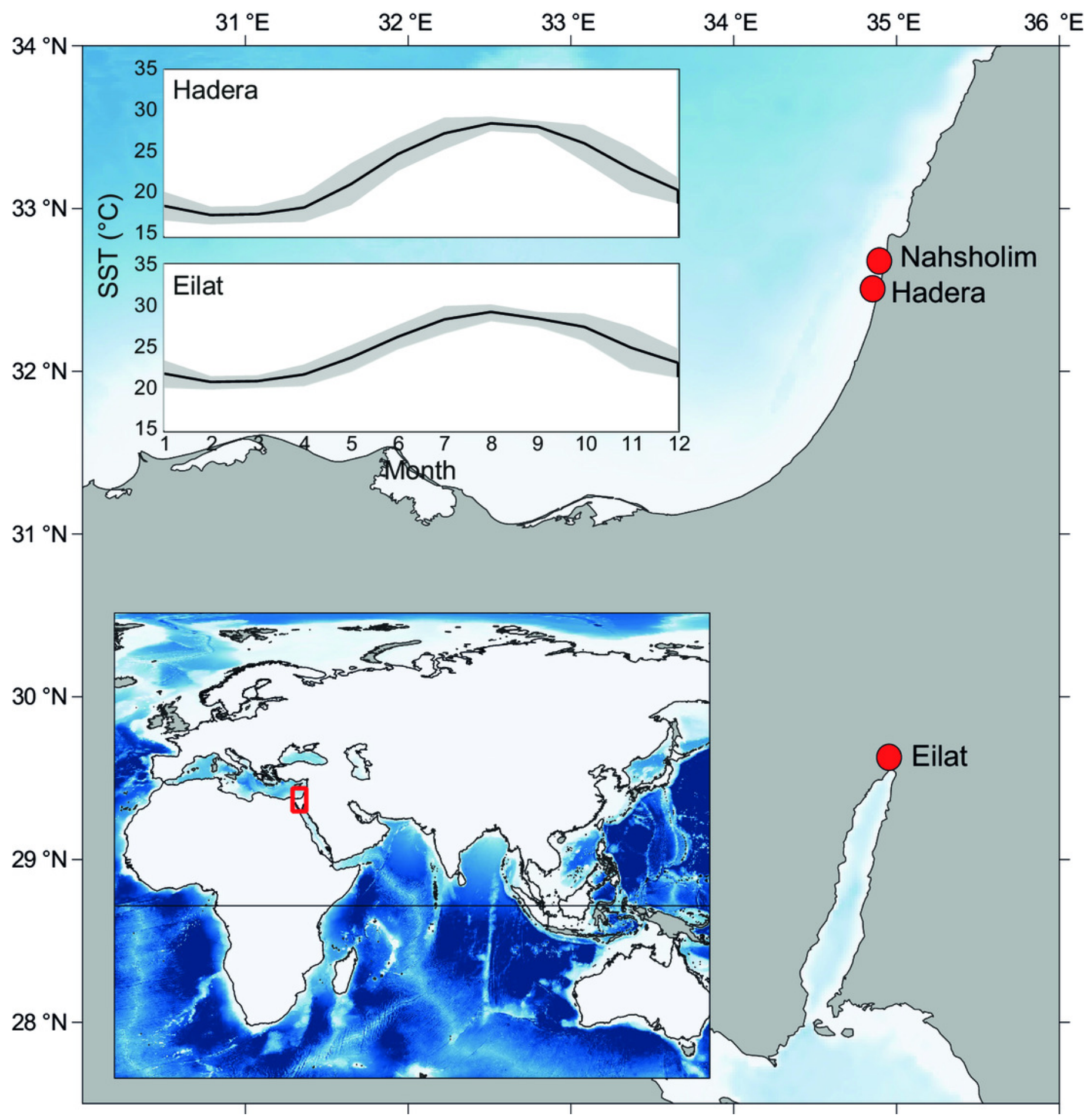




\section{Figure 2}

M. erythraea and M. biserialis sclerites morphology

(A) Spindles and spheroid of $M$. erythraea from Eilat (2017); (B) spindles and spheroid of $M$. biserialis from Eilat (2017); (C) spindles of M. erythraea from Hadera (2016); (D) spindles of M. erythraea from Hadera (2002); and (E) spindles of M. erythraea from Nahsholim (2016). Please note the thicker and denser warts of the Red Sea sclerites with respect to the slender Mediterranean counterparts. Information on the coral sclerites can be found in Kükenthal (1913). 


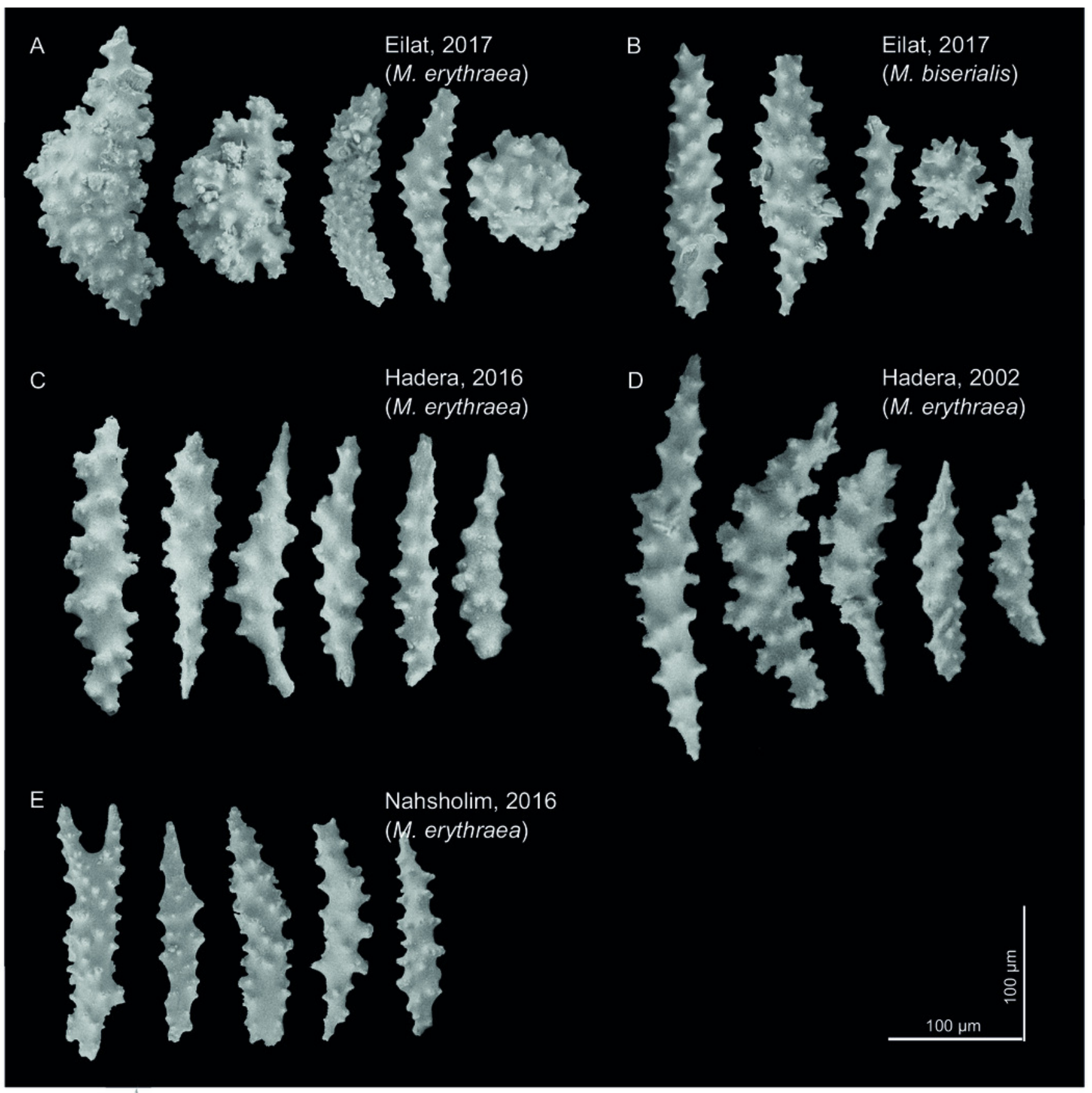


Figure 3

Sclerite morphometrics

(A) Comparison of sclerite width and length from the different sites; (B) Sclerites length-towidth ratio at the different sites; and (C) Wart density along the main sclerites axes at the different sites. $\mathrm{Na}$ - Nahsholim, Ha - Hadera. 

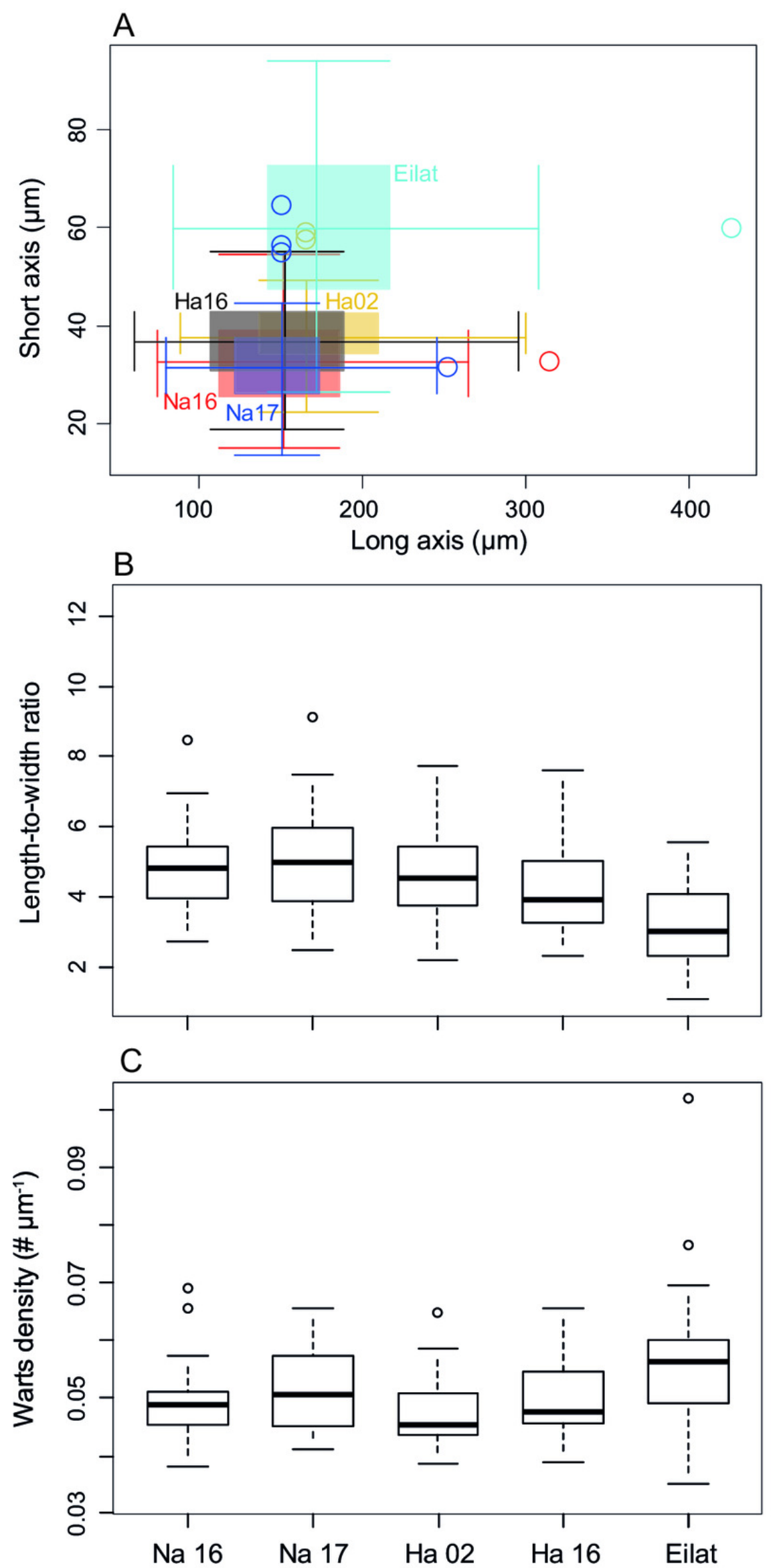

Peer] reviewing PDF | (2020:02:45922:1:1:NEW 15 May 2020) 


\section{Figure 4}

Cross plot of $\delta^{13} \mathrm{C}$ derived metabolic carbon (Eq. 3) and $\delta^{18} \mathrm{O}$ derived temperature (Eq. 1) of sclerite deposition of Melithaea erythraea.

The mean offset of $-1.26 \%$ in $\delta^{13} C_{s c}$ between the Red Sea samples $\left(\delta^{13} \mathrm{C}\right.$ values between -0.28 and $0.30 \%$ ) and the samples collected from the SEMS coast in 2016 and $2017\left(\delta^{13} \mathrm{C}\right.$ values between -1.07 and $-1.42 \%$ ), represent an increase of $\sim 50 \%$ in metabolic carbon intake during calcification. The $2002 \delta^{13} \mathrm{C}_{\mathrm{sc}}$ value of $-0.38 \%$ from Hadera (SEMS) shows an intermediate value between the recent SEMS and Red Sea specimens. 
$\delta^{18} \mathrm{O}_{\mathrm{sC}}$ Temperature of calcification $\left({ }^{\circ} \mathrm{C}\right)$

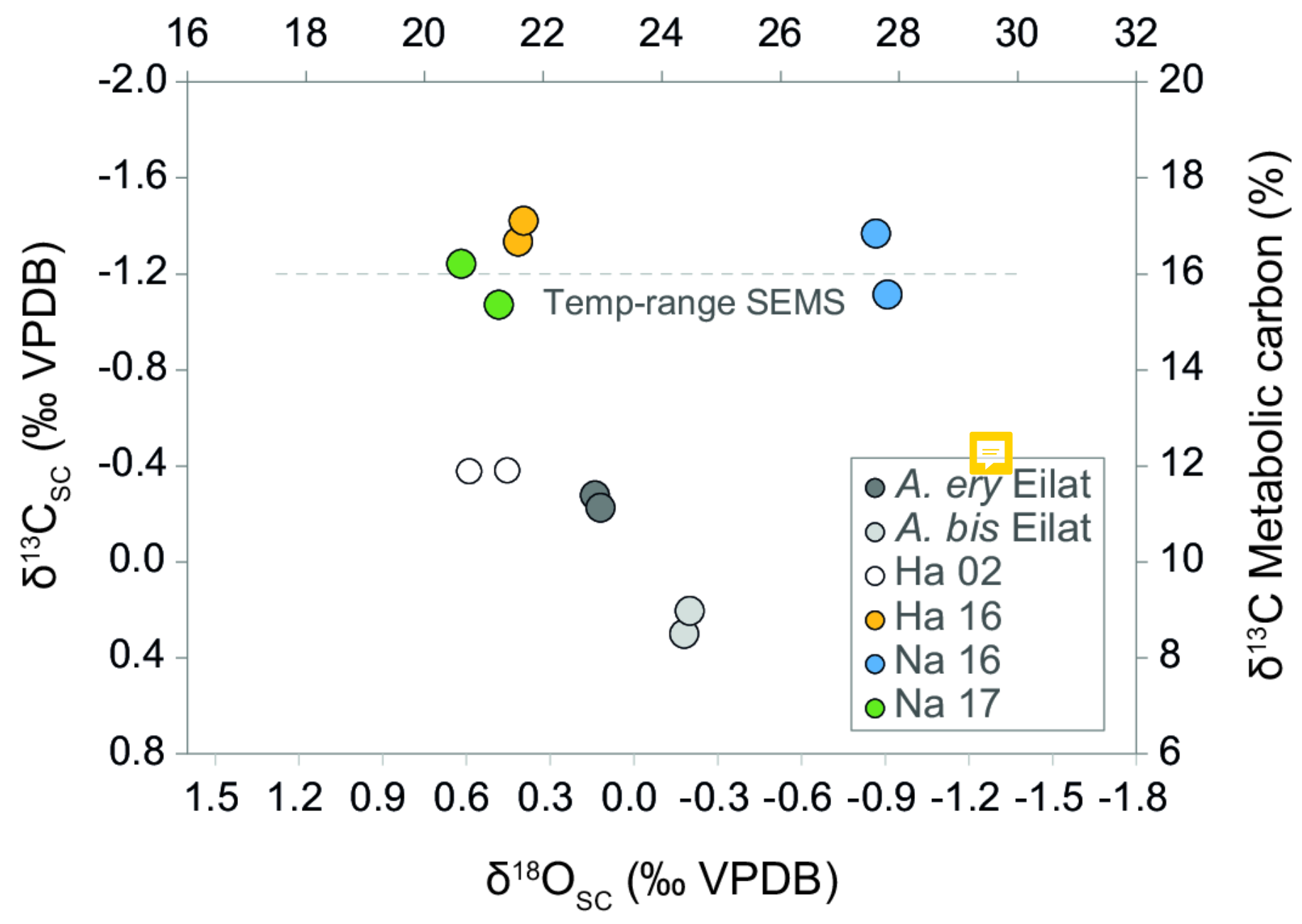


Figure 5

Relation of the M. erythraea sclerite morphometry (length of the long axis)

to (A) its full width at half maximum (FWHM) of the calcite [104] peak and (B) ${ }^{13} \mathrm{C}$ values of the bulkscleritesfor each year.
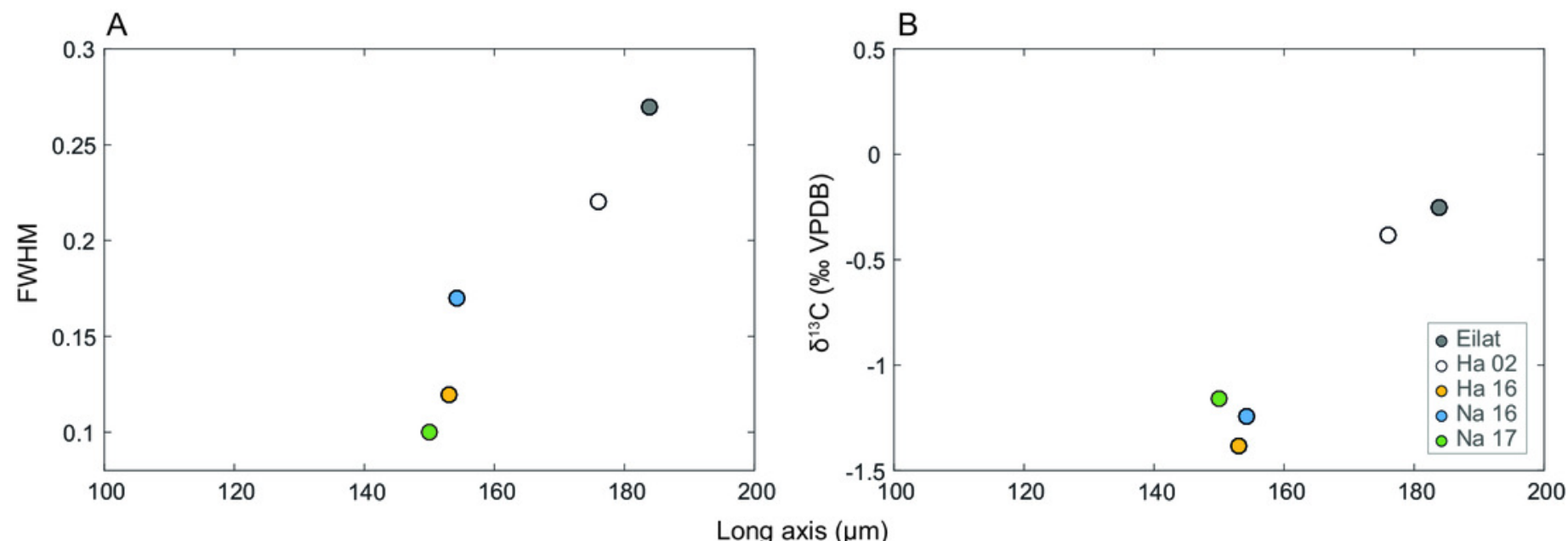


\section{Figure 6}

Variation in sea surface temperature of the Israeli coast (Hadera monitoring station time series, 1994 to 2018).

(A) Stacked annual histograms, the red line traces the lower $10^{\text {th }}$ percentile; (B) Fitted trendline of recorded temperature illustrates the increased warming of water during winters (annually, for the lower 10th percentile).
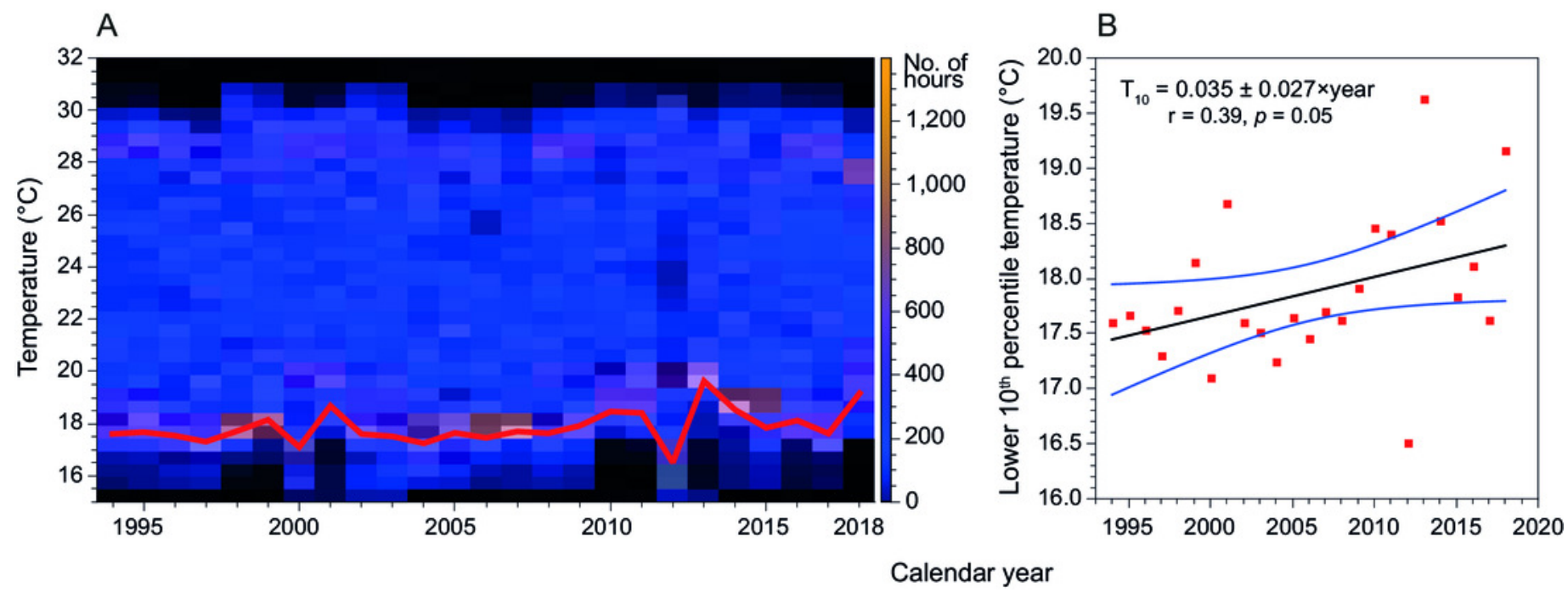


\section{Table $\mathbf{1}$ (on next page)}

Summary table of morphometrics, stable isotopic data, and crystallography

Summary table of morphometrics, stable isotopic data, and crystallography. Detailed results can be found in the Supp. Info. 
Table 1. Summary table of morphometrics, stable isotopic data, and crystallography. Detailed results can be found in the Supp. Info.

\begin{tabular}{|c|c|c|c|c|c|c|c|c|}
\hline & Length-to-width ratio & $\mathrm{n}$ & Warts density $\left(\# \mu \mathrm{m}^{-1}\right)$ & $\mathrm{n}$ & FWHM $(n=1)$ & $\delta^{13} \mathrm{C}(\%)$ & $\delta^{18} \mathrm{O}(\%)$ & $\mathrm{n}$ \\
\hline M. erythraea & & & & & & & & \\
\hline Nahsholim 2017 & $4.97 \pm 1.52$ & 43 & $0.051 \pm 0.007$ & 30 & 0.10 & $-1.159 \pm 0.12$ & $0.363 \pm 0.03$ & 2 \\
\hline Hadera 2016 & $4.14 \pm 1.30$ & 46 & $0.049 \pm 0.006$ & 29 & 0.17 & $-1.242 \pm 0.18$ & $-1.069 \pm 0.04$ & 2 \\
\hline Nahsholim 2016 & $4.77 \pm 1.18$ & 36 & $0.049 \pm 0.006$ & 30 & 0.12 & $-1.380 \pm 0.06$ & $0.207 \pm 0.03$ & 2 \\
\hline Hadera 2002 & $4.55 \pm 1.30$ & 32 & $0.047 \pm 0.006$ & 22 & 0.22 & $-0.381 \pm 0.10$ & $0.331 \pm 0.05$ & 2 \\
\hline Eilat 2017 & $3.18 \pm 1.15$ & 36 & $0.057 \pm 0.013$ & 23 & 0.27 & $-0.250 \pm 0.02$ & $0.033 \pm 0.03$ & 2 \\
\hline $\begin{array}{l}\text { M. biserialis } \\
\text { Eilat } 2017\end{array}$ & $3.58 \pm 2.23$ & 41 & - & - & - & $0.251 \pm 0.03$ & $0.01 \pm 0.04$ & 2 \\
\hline
\end{tabular}

